\title{
Effects of regenerating vegetation on soil enzyme activity and microbial structure in reclaimed soils on a surface coal mine site
}

\author{
Junjian Li ${ }^{\text {a,* }}$, Xiaomei Zhou ${ }^{b}$, Junxia Yan ${ }^{a}$, Hongjian $\mathrm{Li}^{\mathrm{a}}$, Jizheng $\mathrm{He}^{\mathrm{c}}$ \\ a Institute of Loess Plateau, Shanxi University, Wucheng Road 92, Taiyuan, Shanxi 030006, China \\ ${ }^{\mathrm{b}}$ Life Science College, Shanxi University, Taiyuan, Shanxi 030006, China \\ ' State Key Laboratory of Urban and Regional Ecology, Research Centre for Eco-environmental Sciences, Chinese Academy of Sciences, Beijing 100085, China
}

\section{A R T I C L E I N F O}

\section{Article history:}

Received 14 August 2014

Received in revised form 13 November 2014

Accepted 20 November 2014

Available online 29 November 2014

\section{Keywords:}

Reclaimed scenarios

Enzyme activities

Microbial abundance

Microbial structure

\begin{abstract}
A B S T R A C T
The aim of this study was to evaluate the influence of reclaimed scenarios on soil enzyme activities and microbial community in a reclaimed surface coal mine on the Northwest Loess Plateau of China. Soil samples were collected from a bare land (CK), and a plantation (PL) and four mixed forests (MF1-4). Soil physicochemical characteristics, four enzyme activities and microbial abundance and T-RFLP (terminal restriction fragment length polymorphism) profiles were measured. Effects of reclaimed scenarios on soil nutrients content, enzyme activities and microbial community were pronounced. Soil organic carbon could be well used to predict the major differences in enzyme activities, and microbial abundance and composition. Soil enzyme activities were more significantly correlated with fungal abundance than bacterial and archaeal ones. The higher soil nutrient content, enzyme activities, and microbial abundance and diversity were from mixed forests and the lowest ones were from CK, which suggested mixed forests would be feasible scenarios in semi-arid Loess Plateau. Soil bacteria, archaea and fungi evolved with reclaimed process, but the influences of reclaimed scenarios on each domain of microbial abundance, diversity and composition were different. These findings suggested that soil bacteria, archaea and fungi play different ecological roles during restoration process.
\end{abstract}

() 2014 Elsevier B.V. All rights reserved.

\section{Introduction}

Soil enzymes play a fundamental role in nutrient mineralization, organic matter decomposition and plant nutrient cycling. Soil enzyme activities integrate information about microbial status and soil physicochemical conditions (Aon and Colaneri, 2001; Sinsabaugh et al., 2010), and are indicators of the functioning of soil ecosystems (Ciarkowska et al., 2014). They have been similarly used in studies on the effectiveness of reclaimed treatments on soil quality (Li et al., 2012; Schimann et al., 2012; Finkenbein et al., 2013; Ciarkowska et al., 2014). The activity of acid phosphatase may be a useful bioindicator for monitoring soil quality of acid, Pdeficient substrates from subtropical surface coal mines (Finkenbein et al., 2013), and urease and invertase activities can be used as progress indicators for soil-rehabilitation processes in industrial areas (Ciarkowska et al., 2014). Soil enzyme activities were improved by applying weathered coals in reclaimed opencastmining areas of the Loess Plateau of China (Li et al., 2012).

\footnotetext{
* Corresponding author. Tel.: +86 3517010700.

E-mail address: lijunjian@sxu.edu.cn (J. Li).
}

Enzymes are associated with proliferating soil microbial communities, which play a key role in many soil processes and the delivery of essential soil ecosystem services (Gomez-Sagasti et al., 2012). Soil microbial community is one of the most important issues for restoration of sustainable ecosystem in postmining lands because most sites have unfavorable properties (Kaschuk et al., 2010). Soil microbial activities and structure varied with different rehabilitation types and time (Claassens et al., 2008; Dangi et al., 2012; Finkenbein et al., 2013). We applied T-RFLP (terminal restriction fragment length polymorphism) into analyzing the effects of reclaimed scenarios and fertilizer treatments on soil bacterial, archaeal and fungal communities during the initial recovery stage, and found that soil microbial communities were significantly influenced by reclaimed scenarios and T-RFLP was proven powerful in describing differences and changes in soil microbial community structures (Li et al., 2013b).

Mining activities have produced great damage to eco-environment, and legal requirements to reclaim highly disturbed lands are becoming increasingly common (Holl, 2002). Soil enzyme activities and microbial properties have increasingly been used indicators of soil quality to evaluate the success of reclamation efforts (Ciarkowska et al., 2014; Li et al., 2013b Schimann et al., 2012). For the Loess Plateau of China, there are few studies on the 
use of soil enzyme and microbe to assess the success of reclamation in surface coal mines treated with various amendments (Li et al., 2012; Li et al., 2012). In this study, we present soil enzyme activities and microbial abundance and diversity in six soil samples from reclaimed scenarios in surface coal mine, the Northwest Loess Plateau of China. The aim of this study was to describe and evaluate the effects of different reclaimed scenarios on soil properties development and microbe succession.

\section{Materials and methods}

\subsection{Site description and soil sampling}

This study was conducted on reclaimed mine spoils in antaibao opencast coal mining area $\left(39^{\circ} 23^{\prime}-39^{\circ} 23^{\prime} \mathrm{N} ; 112^{\circ} 11^{\prime}-112^{\circ} 30^{\prime} \mathrm{E}\right)$ in Northwest Plateau Loess, China. The altitude is $1300-1400 \mathrm{~m}$. The climate is terrestrial temperate, and the area experiences semi-arid monsoons. Annual average precipitation is about $450 \mathrm{~mm}$, with rainfall occurring mainly from June to September. The annual average air temperature is about $6.2^{\circ} \mathrm{C}$, and the frost-free season ranges in length from 115 to 130 days.

There were six reclaimed scenarios in the reclaimed spoils, including a control site (CK), a plantation (PL) and four mixed forests (MF1-4). The details of vegetation and time since reclamation are listed in Table 1. In September, 2011, the upper $10 \mathrm{~cm}$ of soil was collected from 6 random locations within a given plot of $\approx 00 \mathrm{~m}^{2}$ and composited into a single bulk sample in triplicate at each site. After removing stones and large pieces of plant materials, soil samples were sieved to $2 \mathrm{~mm}$ and homogenized, and subsamples for microbial analysis were stored at $4{ }^{\circ} \mathrm{C}$ and the other ones for chemical analysis were air dried.

2. 2. Soil chemical properties and enzyme activities

Soil $\mathrm{pH}$ in $\mathrm{dH}_{2} \mathrm{O}$ was measured using a glass combination electrode in subsets of air-dried soils at a soil: solution ratio of $1: 2.5$. Soil organic carbon (SOC) was determined by the dichromate oxidation method. Total, available and ammonium nitrogen (TN, AVN and AMN) were determined by the Kjeldahl method, alkaline hydrolysis diffusion method and indophenol-blue colorimetry, respectively (Lu, 2000). We used 3,5-dinitrosalicylic acid colorimetry, 2,3,5-triphenyl tetrazolium colorimetry, pyrogallol colorimetry and indophenol-blue colorimetry to measure soil invertase, dehydrogenase, polyphenol oxidase and urease activities, respectively (Guan, 1986).

\subsection{PCR assay for real-time quantification and T-RFLP}

DNA was extracted from $0.5 \mathrm{~g}$ soil using the Ultra-clean TM soil DNA Isolation Kits (MoBio Laboratory, USA) according to the manufacturer's protocol. The DNA extracts were 100-fold diluted and used as template with a final content of $1-10 \mathrm{ng}$ in each reaction mixture to amplify soil microbial rRNA genes.

Real-time PCR was performed on an iCycler iQ-5 thermocycler (Bio-Rad). We use the probe TM189F and Premix Ex Taq ${ }^{\mathrm{TM}}$ (Takara

Table 1

The reclaimed vegetation composition and time.

\begin{tabular}{llc}
\hline & Vegetation & Reclaimed time $(a)$ \\
\hline CK & Reclaimed area covered with soil in 2009 & 1 \\
PL & Robinia pseudoacacia & 18 \\
MF1 & R. pseudoacacia,Pinus tabuliformis & 18 \\
MF2 & Hippophae rhamnoides, Caragana Korshinskii & 18 \\
MF3 & C. Korshinskii, Elaeagnus angustifolia, Ulmus pumila & 18 \\
MF4 & H. rhamnoides, C. Korshinskii, E. angustifolia & 18 \\
\hline
\end{tabular}

Biotechnology, Japan) to analysis bacterial 16S rRNA gene quantitative assay. SYBR ${ }^{\circledR}$ Premix Ex TaqTM with Green I (Takara Biotechnology, Japan) was applied into the reaction mixture for quantifying archaeal and fungal rRNA gene. We use primers labeled at the $5^{\prime}$-end with the reporter dye FAM (6-carboxyfluorescein) for T-RFLP analysis. The detailed information on primer, probe, and PCR condition were described in our previous study (Li et al., 2013a).

\subsection{T-RFLP analysis}

We used 1\% agarose gel electrophoresis and purified with Wizard ${ }^{\circledR}$ SV Gel and PCR Clean-Up System (Promega, USA) to verify PCR products. Restriction endonucleases HhaI and MspI (Takara Biotechnology, Japan) digested purified products, respectively, and the reactions including $4 \mathrm{U}$ of enzyme and about $500 \mathrm{ng}$ of DNA were incubated at $37^{\circ} \mathrm{C}$ for $3 \mathrm{~h}$ in the manufacturer's recommended reaction buffer. Further purified digestion products was mixed with deionized formamide and the internal standard GeneScan-ROX1000 (bacteria)/LIZ 500 (archaea and fungi) (Applied Biosystems) and denatured for $3 \mathrm{~min}$ at $95^{\circ} \mathrm{C}$. The DNA fragments were size separated using a 3130xl Genetic Analyzer (Applied Biosystems).

\subsection{Statistical analysis}

The effects of regenerating vegetation on soil chemical properties, enzyme activities and microbial characteristics were examined through one-way analysis of variance (ANOVA) with Duncan test. We used Person linear correlation to determine whether there was significant correlation among tested abiotic and biotic characteristics. Spearman rank correlation was examined microbial RFs-pairs association. These statistical analyses were performed using SPSS 13.0 for Windows.

We analyzed soil microbial richness, diversity and evenness according to restricted fragments (RFs). Richness, ShannonWiener diversity, Simpson diversity and Pielou evenness indices were computed according to the number and relative ratios of RFs (Li et al., 2013a).

The weighted value of bacteria, archaea and fungi were ranked 4,3 and 3, respectively, according to the ratios of logarithm the bacterial, archaeal and fungal rRNA gene copies. The matrices of RFs ratios for bacteria, archaea, fungi and total microbe were used as the basis of the community analysis. A matrix of environmental factors was applied into analyzing the relationships between the reclaimed scenarios and environmental factors using canonical correspondence analysis (CCA). CCA was performed using the CANOCO (Ter Braak and Šamilauer 2002), and we used the Monte Carlo permutation test to test the significant level $(P<0.05)$ between environmental data and microbial matrices.

Table 2

Soil pH, organic carbon (SOC), total, available and ammonium nitrogen (TN, AVN and $\mathrm{AMN}$ ) from different reclaimed scenarios in the reclaimed mining area.

\begin{tabular}{llllll}
\hline & $\mathrm{pH}$ & $\mathrm{SOC}(\mathrm{g} / \mathrm{kg})$ & $\mathrm{TN}(\mathrm{g} / \mathrm{kg})$ & AVN $(\mathrm{mg} / \mathrm{kg})$ & AMN $(\mathrm{mg} / \mathrm{kg})$ \\
\hline $\mathrm{CK}$ & $7.47 \pm 0.14 \mathrm{a}$ & $6.00 \pm 0.62 \mathrm{a}$ & $4.27 \pm 0.81 \mathrm{a}$ & $38.27 \pm 7.05 \mathrm{a}$ & $6.62 \pm 0.69 \mathrm{a}$ \\
$\mathrm{PL}$ & $7.33 \pm 0.05 \mathrm{a}$ & $16.61 \pm 0.94 \mathrm{c}$ & $5.93 \pm 0.75 \mathrm{~b}$ & $73.73 \pm 4.28 \mathrm{~b}$ & $15.46 \pm 0.42 \mathrm{c}$ \\
MF1 & $7.33 \pm 0.15 \mathrm{a}$ & $33.00 \pm 3.37 \mathrm{e}$ & $10.80 \pm 0.26 \mathrm{~d}$ & $123.20 \pm 4.85 \mathrm{~d}$ & $12.62 \pm 1.34 \mathrm{~b}$ \\
MF2 & $7.50 \pm 0.12 \mathrm{a}$ & $11.55 \pm 0.86 \mathrm{~b}$ & $4.30 \pm 0.20 \mathrm{a}$ & $31.73 \pm 3.23 \mathrm{a}$ & $13.57 \pm 1.17 \mathrm{~b}$ \\
MF3 & $7.38 \pm 0.14 \mathrm{a}$ & $25.80 \pm 1.56 \mathrm{~d}$ & $7.93 \pm 0.12 \mathrm{c}$ & $80.73 \pm 3.52 \mathrm{~b}$ & $16.68 \pm$ \\
& & & & & $0.58 \mathrm{c}$ \\
MF4 & $7.45 \pm 0.09 \mathrm{a}$ & $27.67 \pm 2.15 \mathrm{~d}$ & $7.27 \pm 1.10 \mathrm{c}$ & $92.40 \pm 4.85 \mathrm{c}$ & $15.23 \pm 0.83 \mathrm{c}$
\end{tabular}

Data are means \pm standard deviations. The different case letters indicate that the means are significantly different among reclaimed scenario $(P<0.05)$ with Duncan test. 
Table 3

Soil invertase, dehydrogenase, polyphenol oxidase and urease activities in the reclaimed mining area.

\begin{tabular}{|c|c|c|c|c|}
\hline & Invertase (mg/kg h) & Dehydrogenase (mg/kg h) & Polyphenol oxidase $(\mathrm{mg} / \mathrm{kg} \mathrm{h})$ & Urease $(\mathrm{mg} / \mathrm{kg} \mathrm{h})$ \\
\hline CK & $151.68 \pm 26.02 \mathrm{a}$ & $122.23 \pm 7.30 \mathrm{a}$ & $30.41 \pm 0.55 a$ & $0.17 \pm 0.05 a$ \\
\hline PL & $455.04 \pm 31.03 b$ & $172.80 \pm 31.82 b c$ & $44.11 \pm 0.42 b$ & $0.14 \pm 0.06 a$ \\
\hline MF1 & $844.57 \pm 31.59 \mathrm{e}$ & $206.52 \pm 19.31 c$ & $78.67 \pm 0.84 \mathrm{e}$ & $0.68 \pm 0.10 c$ \\
\hline MF2 & $492.95 \pm 4.18 b c$ & $147.51 \pm 31.64 a$ & $50.91 \pm 0.55 c$ & $0.36 \pm 0.10 b$ \\
\hline MF3 & $530.87 \pm 15.80 c$ & $164.41 \pm 23.27 \mathrm{ab}$ & $59.04 \pm 0.62 d$ & $0.43 \pm 0.06 b$ \\
\hline MF4 & $720.47 \pm 31.59 d$ & $193.87 \pm 26.32 c$ & $74.75 \pm 0.76 \mathrm{e}$ & $0.62 \pm 0.07 \mathrm{c}$ \\
\hline
\end{tabular}

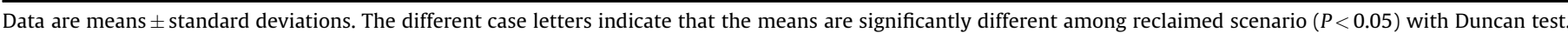

\section{Results}

\subsection{Soil chemical properties}

Compared to control study site (CK), five reclaimed scenarios significantly improved soil nutrients, however, they did not influence soil pH (Table 2). The values of SOC, TN and AVN from MF1 sites were the highest among reclaimed scenarios, and the lowest ones were from MF2 sites.

\subsection{Soil enzyme activities}

There were significant differences on soil invertase, dehydrogenase, polyphenol oxidase and urease activities among reclaimed scenarios (Table 3). Soil enzyme activities form MF1 and MF4 sites kept significantly higher than those from other sites. Soil enzyme activities from CK site were low, and soil invertase and polyphenol oxidase activities were significantly lower than other sites. Soil invertase and polyphenol oxidase activities demonstrated more sensitive to reclaimed scenarios than other two enzyme activities.

\subsection{Soil bacterial, archaeal and fungal abundance}

Soil bacterial, archaeal and fungal rRNA gene abundance from study sites are demonstrated in Fig. 1. Soil bacterial abundance from CK site significantly differed from 4 mixed forests (MF1-4), however, little differences from plantation (PL). Soil archaeal rRNA gene from MF1 was significantly most abundant among study sites. Soil archaeal abundance from CK site was significantly lower than that from MF1 and MF4. Soil fungal rRNA gene abundance from MF1 was the highest and significantly different from other sites, except for MF4.

\subsection{Soil microbial T-RFLP characteristics}

Soil bacterial, archaeal, and fungal T-RFLP profiles from the study sites were produced with endonucleases HhaI and MspI, and

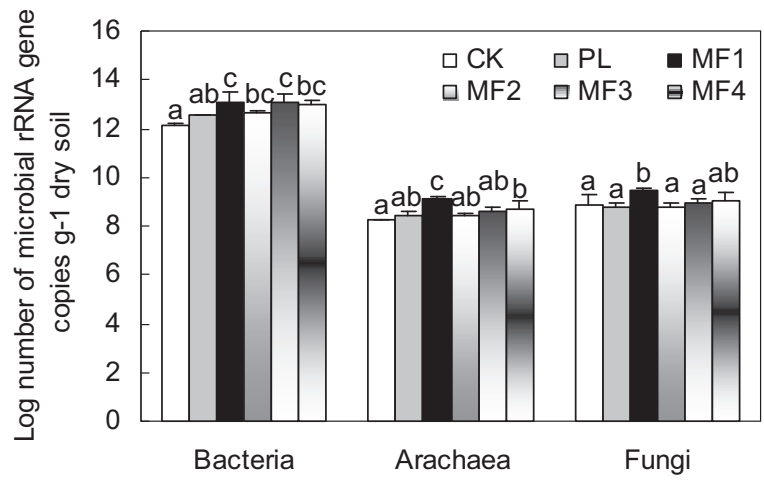

Fig. 1. Abundance of soil bacteria, archaea, and fungi rRNA genes in the reclaimed mining area. Points show the means of three replicates, and vertical bars show standard deviations. The different case letters indicate that the means are significantly different among reclaimed scenario $(P<0.05)$ with Duncan test. the relative fluorescence intensity of RFs restricted with endonucleases differed with reclaimed scenarios. We only showed the TRFLP profiles restricted with Hhal (Fig. 2). Soil bacterial highest relative abundance RFs were different among sites (60 bp for CK and MF2, $208 \mathrm{bp}$ for PL and MF1, $230 \mathrm{bp}$ for MF3, and $90 \mathrm{bp}$ for MF4). $187 \mathrm{bp}$ archaeal RFs was the most abundant and accounted for more than half for study sites, except for MF4. Soil fungal $350 \mathrm{bp}$ RFs was the highest for MF4, and 257 bp RFs was the highest for
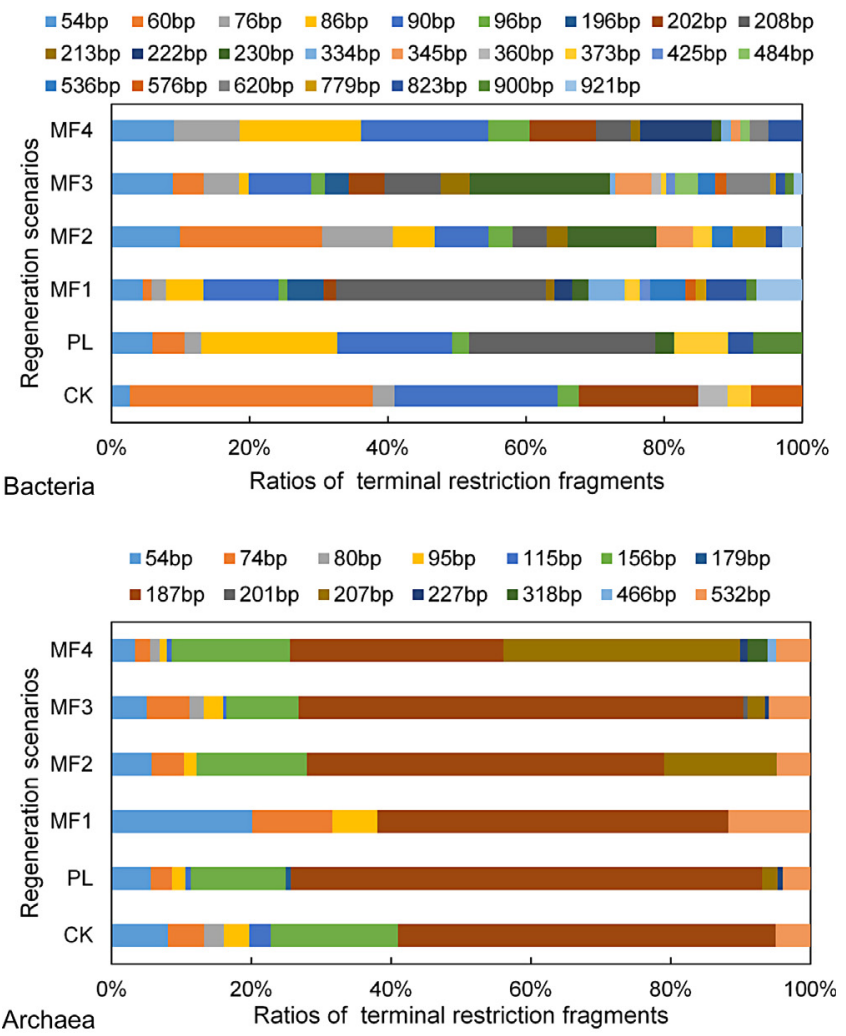

$\because 151 \mathrm{bp}=158 \mathrm{bp}-254 \mathrm{bp}=257 \mathrm{bp}=262 \mathrm{bp}\|266 \mathrm{bp}=284 \mathrm{bp}\| 324 \mathrm{bp}$

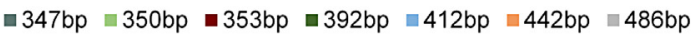

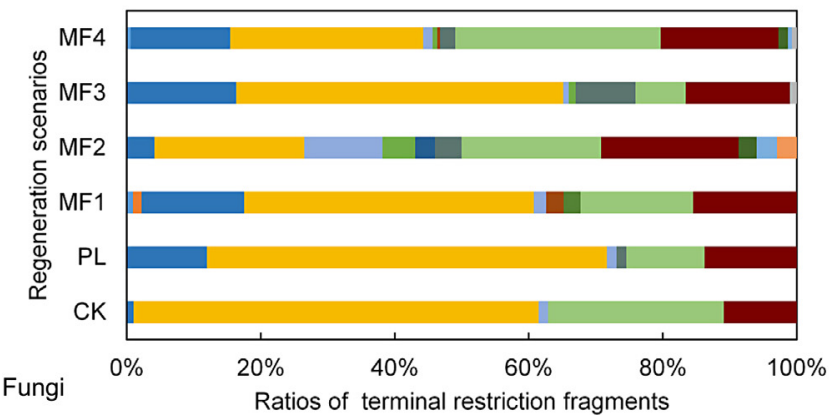

Fig. 2. Relative fluorescence of soil bacteria, archaea and fungi populations from study sites in reclaimed mining area monitored by T-RFLP electropherogram target on rRNA gene sequences digested with Hhal restriction enzymes. 

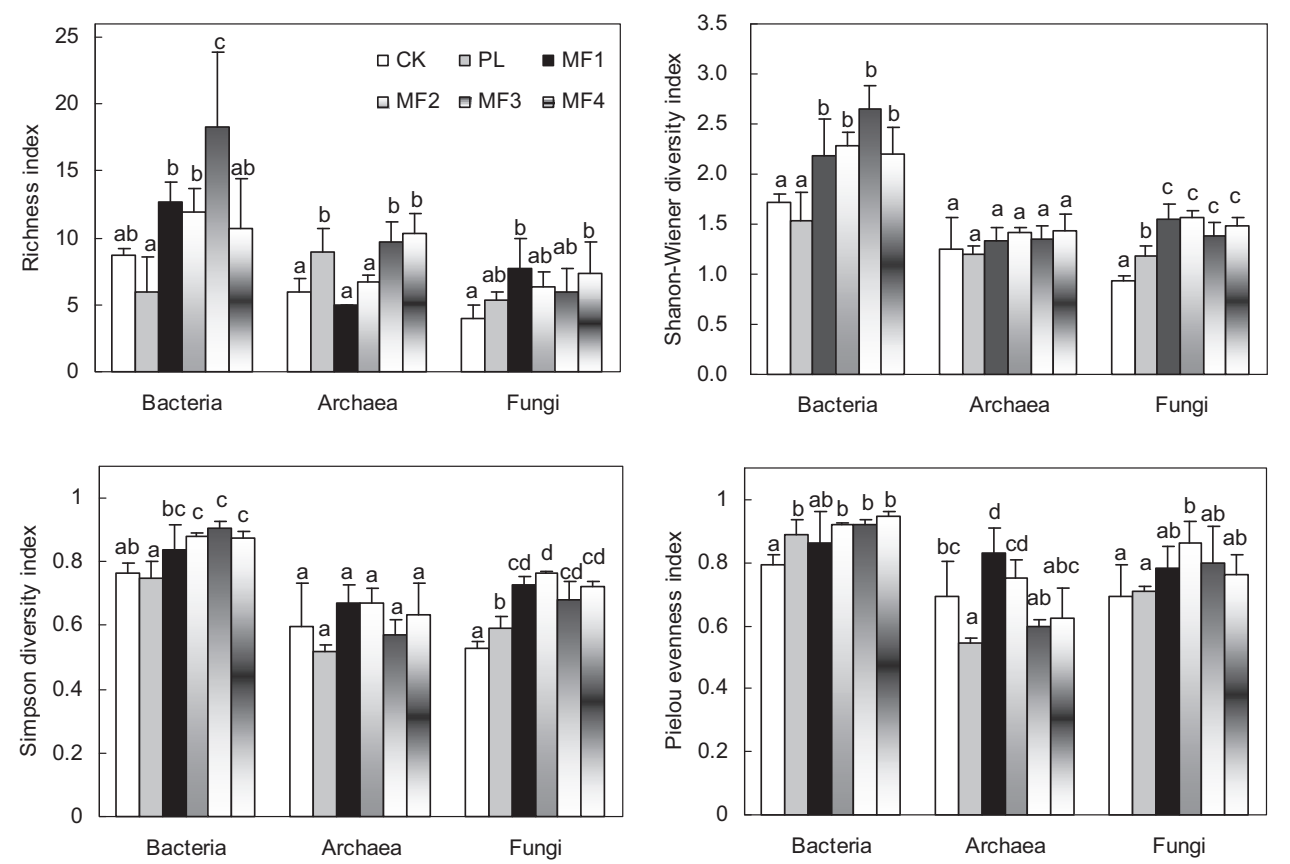

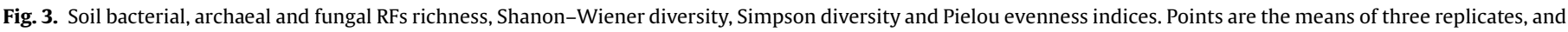

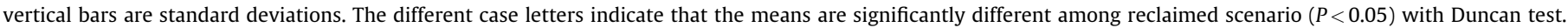

Table 4

Ratios of the inter-RFs positive and negative association drawn from Spearman rank correlation test for soil bacteria, archaea, fungi and total microbe under different reclaimed scenarios, in reclaimed mining area.

\begin{tabular}{lllll}
\hline & Bacteria & Archaea & Fungi & Total microbe \\
\hline CK & 0.64 & 0.62 & 0.67 & 0.88 \\
PL & 0.71 & 0.57 & 0.75 & 0.95 \\
MF1 & 0.98 & 1.00 & 1.00 & 1.01 \\
MF2 & 0.94 & 0.64 & 0.67 & 0.90 \\
MF3 & 0.91 & 0.96 & 0.70 & 1.04 \\
MF4 & 0.88 & 1.00 & 0.74 & 0.90 \\
\hline
\end{tabular}

other sites. There were specific RFs of three domains microbe for each reclaimed scenarios.

\subsection{Soil microbial diversity}

Soil bacterial, archaeal, and fungal RF richness, diversity, and evenness indices according to RFs produced by Hhal are in Fig. 3. Soil bacterial richness and diversity indices from four mixed forests were significantly higher than those from CK and PL. For soil bacterial evenness index, the only significant differences were found between control sites and reclaimed scenarios (except for MF1). There were no pronounced differences on archaeal diversity indices among sites, and the significant effects of reclaimed scenarios on richness and evenness indices. Soil fungal richness index from CK differed significantly from MF1 and MF4. Soil fungal diversity indices form mixed forests were significantly higher than those from CK and PL, and there were significantly differences between $\mathrm{CK}$ and PL. Soil fungal evenness index from MF2 significantly differed from CK and PL.

\subsection{Spearman rank correlation test for microbial community}

The results of the Spearman rank correlation test of soil microbial RF correlation are listed in Table 4. We found that the highest RF-pair ratios of positive and negative association for each microbial community were in MF2. The lowest ratios for bacteria, fungi and total microbe were in $\mathrm{CK}$, and the lowest ones for archaea were in PL. Compared to CK and PL, mixed forests were with higher ratios of positive and negative association for soil bacteria and archaea. The higher fungal and total microbial ratios were found in PL.

\subsection{Relationships between soil factors, enzymes and microbes}

The Pearson correlations among soil chemical properties, enzyme activities and microbial rRNA gene abundances are listed

Table 5

The Pearson correlations among soil chemical properties, enzyme activities and microbial rRNA gene abundances in reclaimed mining area.

\begin{tabular}{|c|c|c|c|c|c|c|c|c|c|c|c|}
\hline & $\mathrm{pH}$ & SOC & $\mathrm{TN}$ & AVN & AMN & Invertase & Dehydrogenase & Polyphenol oxidase & Urease & Bacteria & Archaea \\
\hline SOC & ns & & & & & & & & & & \\
\hline TN & ns & $* *$ & & & & & & & & & \\
\hline AVN & ns & $* *$ & $* *$ & & & & & & & & \\
\hline AMN & ns & ns & ns & ns & & & & & & & \\
\hline Invertase & ns & $* *$ & * & $*$ & ns & & & & & & \\
\hline Dehydrogenase & ns & $* *$ & * & $* *$ & ns & $* *$ & & & & & \\
\hline Polyphenol oxidase & ns & $* *$ & * & $*$ & ns & $* *$ & $*$ & & & & \\
\hline Urease & ns & $*$ & ns & ns & ns & $*$ & ns & $* *$ & & & \\
\hline Bacteria & ns & $* *$ & ns & ns & ns & $*$ & ns & * & $*$ & & \\
\hline Archaea & ns & $* *$ & $* *$ & $* *$ & ns & $*$ & $*$ & $*$ & $*$ & ns & \\
\hline Fungi & ns & $* *$ & $*$ & $*$ & ns & $* *$ & $* *$ & $* *$ & $\mathrm{~ns}$ & $*$ & $*$ \\
\hline
\end{tabular}

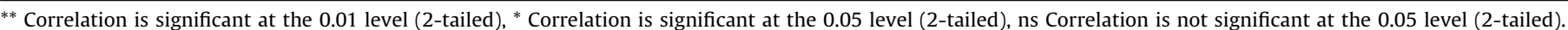


in Table 5. Soil pH and AMN did not correlate with any other properties, however, SOC correlated with enzyme activities (except urease) and microbial abundance at 0.001 level. Except for urease activities, other three enzyme activities more significantly were correlated with fungal rRNA abundances than bacterial and archaeal ones.

CCA revealed that the tested soil factors clustered into two directions attributed to the variation in microbial communities (Fig. 4), and the significant factors were different for three domains of microbes (Table S1). AVN played noticeable roles in each of the microbial community division, however, pH demonstrated little influences on microbial community composition (Table S1). The first two axes represented $80.4 \%$ of the cumulative percentage variance of species-environment relation for archaeal community, and 64.1-69.9\% for other microbial communities (Fig. 4). Soil microbial communities from CK and PL reversed to the vectors of environmental factors.

\section{Discussion}

Soil enzymes are specific to a substrate and have active sites that bind with the substrate to form a temporary complex. We found that the reclaimed scenarios significantly improved soil organic matters compared to $\mathrm{CK}$ site (Table 2). High soil concentrations of organic matter in the reclaimed treatments resulted to enzyme activities increasing (Table 3 ), and we also observed that soil enzyme activities were positively correlated with SOC, TN and AVN (Table 5). This is in accordance with those of Ciarkowska et al. (2014), who found the high variability of SOC and $\mathrm{TN}$ in the examined soil samples was reflected by the large differences in enzyme activities and the enzyme activities were positively correlated with the carbon and nitrogen concentrations. During spontaneous succession in spoil heaps after brown coal mining, the major determinants of enzyme activity were the contents of SOC and TN in topsoil layer (Baldrian et al., 2008). There were significant differences on soil nutrient content and enzyme activities across five reclaimed scenarios (Table 2), which is in agreement with a previous study that soil nutrient content closely correlate with the changes in the vegetation cover (Frouz and Novakova, 2005). The effects of reclaimed scenarios on enzyme activities might be determined by two major drivers (1) substrate induction due to litter inputs of above-ground vegetation seemed to influence soil enzyme activities (Tischer et al., 2014); and (2) plant roots produced varied stimulations on enzyme activities because of their different effects on microbial activity and production of exudates rich in substrates (Salam et al., 1998). Based on Biolog-Eco technology, the different carbon sources due to vegetation restoration patterns significantly influenced the metabolic activity and functional diversity of microbial community in sandy soil (Zhang et al., 2013).

Soil pH is an important regulator of soil microbial communities and enzyme activities at the continental or global scale (Sinsabaugh et al., 2008; Lauber et al., 2009). In our study, little differences in $\mathrm{pH}$ among reclaimed scenarios resulted in no
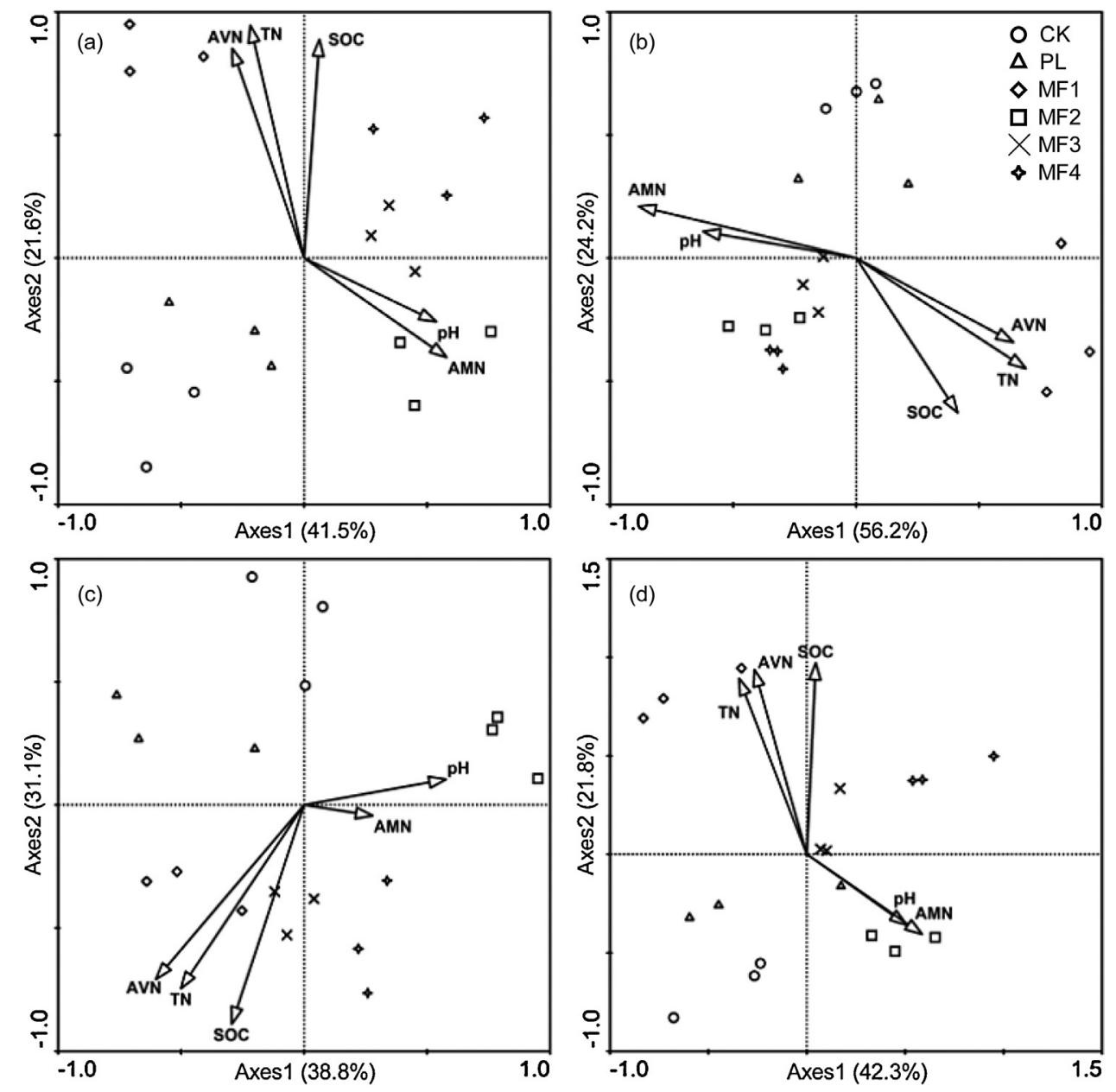

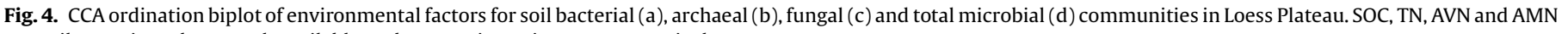
are soil organic carbon, total, available and ammonium nitrogen, respectively. 
correlations between $\mathrm{pH}$ and enzyme activities or microbial abundance (Table 5). Through the Monte Carlo permutation test, we also observed soil $\mathrm{pH}$ was not a significant environmental factor for soil microbial composition (Table S1). Lauber et al. (2009) reported that soil $\mathrm{pH}$ did not correlate with microbial phylogenetic diversity, and suggested that biodiversity might be controlled by substrate, environmental factors or biotic competitiveness in semiarid soils (Girvan et al., 2003; Fierer and Jackson, 2006).

Soil bacterial, archaeal and fungal abundance demonstrated different correlations with four enzyme activities in the present study (Table 5), and the more pronounced correlations were between fungal abundance with enzyme activities. This finding supported that fungi contribute significantly to soil enzyme activities. Fungal biomass is reported to explain a large extent differences on soil enzyme activities between field and meadow soils, as the bacterial community structures were similar among these land use types (Wallenius et al., 2011). The ratios of fungal to bacterial biomass also correlated with enzyme activities with succession process because the elevated ratio can be a sign for the amount and composition of litter that enters the soil since fungi are the dominant decomposers of plant cell wall polymers in the litter (Baldrian et al., 2008). Although there were little significant differences between each study sites, we found MF2 with highest ratios of fungi to bacteria had the highest enzyme activities in present study (Table S2), which could be explained by the significantly increased fungal abundance with greater plant diversity (Hamilton and Frank, 2001).

The effect of vegetation was evaluated as a significant factor for the development of microbial soil properties in several previous reclaimed treatment studies (Li et al., 2013b Frouz and Novakova, 2005; Šourková et al., 2005). In our study, reclaimed scenarios were found to determine soil microbial abundance, diversity and composition. SOC not only positively correlated with microbial abundance (Table 5), but also was a significant environmental factor for microbial CCA patterns (Fig. 4). Soil organic matter is determined factor for soil microbial community structure has been reported repeatedly (Lupatini et al., 2013; Yoshitake et al., 2013). These indicated that the significant effect of vegetation on soil microbial community might be up to the differences on litter input and roots exudates (Han et al., 2007; Lambers et al., 2009). Mixed forests provide abundant media for microbe, therefore, we found that the higher microbial abundance and diversity were in mixed forests than PL and CK. It is well known that the higher species diversity means the higher community stability for vegetation. In the present study, the higher RF-pair ratios of positive and negative association was from the plot with higher diversity (Fig. 3, and Table 4). In previous studies on different regeneration scenarios in Loess Plateau, higher microbial abundance were from mixed forests than plantations (Li et al., 2013a,b; Li et al., 2013a). There were specific RFs for each reclaimed scenarios (Fig. 2), which is accounted for each plant species uniquely contributing to the functioning of the belowground system (Eisenhauer et al., 2010; Mariotte et al., 2013).

Three domains of microbial abundances and diversity showed different responds to reclaimed scenarios (Figs. 1 and 3), and fungal diversity indices were sensitive to reclaimed scenarios in most cases. However, archaeal diversity indices were sensitive to reclaimed treatments for the initial reclaimed phase on a surface coal mine (Li et al., 2013b). Bissett et al. (2011) reported that all soils showed similar levels of bacterial diversity although community structure (bacterial, archaeal, fungal) differed under all treatments. Bacteria played an important role in ecological stability during initial restoration period (Li et al., 2013a), and forest succession promoted soil fungal dominated community (Susyan et al., 2011). In addition, there are differences in ecological roles of archaea and bacteria in the same environments (Aller and
Kemp, 2008). In the pampa biome, fungal community structure was more affected by land-use and archaeal community was more affected by soil type (Lupatini et al., 2013). These results suggested that soil bacteria, archaea and fungi play different ecological roles, therefore, new studies should be directed toward three domains of microbial community composition with advanced techniques.

\section{Appendix A. Supplementary data}

Supplementary data associated with this article can be found, in the online version, at http://dx.doi.org/10.1016/j. apsoil.2014.11.010.

\section{References}

Aller, J.Y., Kemp, P.F., 2008. Are archaea inherently less diverse than bacteria in the same environments? Fems Microbiol. Ecol. 65, 74-87.

Aon, M.A., Colaneri, A.C., 2001. II. Temporal and spatial evolution of enzymatic activities and physico-chemical properties in an agricultural soil. Appl. Soil Ecol. $18,255-270$.

Baldrian, P., Trogl, J., Frouz, J., Snajdr, J., Valaskova, V., Merhautova, V., Cajthaml, T., Herinkova, J., 2008. Enzyme activities and microbial biomass in topsoil layer during spontaneous succession in spoil heaps after brown coal mining. Soil Biol. Biochem. 40, 2107-2115.

Bissett, A., Richardson, A.E., Baker, G., Thrall, P.H., 2011. Long-term land use effects on soil microbial community structure and function. Appl. Soil Ecol. 51, 6678.

Ciarkowska, K., Sołek-Podwika, K., Wieczorek, J., 2014. Enzyme activity as an indicator of soil-rehabilitation processes at a zinc and lead ore mining and processing area. J. Environ. Manage. 132, 250-256.

Claassens, S., van Rensburg, P.J.J., Maboeta, M.S., van Rensburg, L., 2008. Soil microbial community function and structure in a post-mining chronosequence. Water Air Soil Poll. 194, 315-329.

Dangi, S.R., Stahl, P.D., Wick, A.F., Ingram, L.J., Buyer, J.S., 2012. Soil microbial community recovery in reclaimed soils on a surface coal mine site. Soil Sci. Soc. Am. J. 76, 915-924.

Eisenhauer, N., Bessler, H., Engels, C., Gleixner, G., Habekost, M., Milcu, A., Partsch, S., Sabais, A.C.W., Scherber, C., Steinbeiss, S., Weigelt, A., Weisser, W.W., Scheu, S., 2010. Plant diversity effects on soil microorganisms support the singular hypothesis. Ecology 91, 485-496.

Fierer, N., Jackson, R.B., 2006. The diversity and biogeography of soil bacterial communities. Proc. Natl. Acad. Sci. USA 103, 626-631.

Finkenbein, P., Kretschmer, K., Kuka, K., Klotz, S., Heilmeier, H., 2013. Soil enzyme activities as bioindicators for substrate quality in revegetation of a subtropical coal mining dump. Soil Biol. Biochem. 56, 87-89.

Frouz, J., Novakova, A., 2005. Development of soil microbial properties in topsoil layer during spontaneous succession in heaps after brown coal mining in relation to humus microstructure development. Geoderma 129, 54-64.

Girvan, M.S., Bullimore, J., Pretty, J.N., Osborn, A.M., Ball, A.S., 2003. Soil type is the primary determinant of the composition of the total and active bacterial communities in arable soils. Appl. Environ. Microbiol. 69, 1800-1809.

Gomez-Sagasti, M.T., Alkorta, I., Becerril, J.M., Epelde, L., Anza, M., Garbisu, C., 2012. Microbial monitoring of the recovery of soil quality during heavy metal phytoremediation. Water Air Soil Poll. 223, 3249-3262.

Guan, S.Y., 1986. Study Way of Soil Enzymes. Agriculture press, Beijing, China.

Hamilton, E.W., Frank, D.A., 2001. Can plants stimulate soil microbes and their own nutrient supply? Evidence from a grazing tolerant grass. Ecology 82, 2397-2402.

Han, X.M., Wang, R.Q., Liu, R., Wang, M.C., Zhou, J., Guo, W.H., 2007. Effects of vegetation type on soil microbial community structure and catabolic diversity assessed by polyphasic methods in North China. J. Environ. Sci-China 19, $1228-1234$

Holl, K.D., 2002. Long-term vegetation recovery on reclaimed coal surface mines in the eastern USA. J. Appl. Ecol. 39, 960-970.

Kaschuk, G., Alberton, O., Hungria, M., 2010. Three decades of soil microbial biomass studies in Brazilian ecosystems: lessons learned about soil quality and indications for improving sustainability. Soil Biol. Biochem. 42, $1-13$.

Lambers, H., Mougel, C., Jaillard, B., Hinsinger, P., 2009. Plant-microbe-soil interactions in the rhizosphere: an evolutionary perspective. Plant Soil 321, 83-115.

Lauber, C.L., Hamady, M., Knight, R., Fierer, N., 2009. Pyrosequencing-based assessment of soil ph as a predictor of soil bacterial community structure at the continental scale. Appl. Environ. Microbiol. 75, 5111-5120.

Li, H., Shao, H., Li, W., Bi, R., Bai, Z., 2012. Improving soil enzyme activities and related quality properties of reclaimed soil by applying weathered coal in opencastmining areas of the Chinese Loess Plateau. Clean - Soil Air Water 40, 233-238. 
Li, J.J., Zheng, Y.M., Yan, J.X., Li, H.J., He, J.Z., 2013a. Succession of plant and soil microbial communities with restoration of abandoned land in the Loess Plateau, China. J. Soil Sediments 13, 760-769.

Li, J.J., Zheng, Y.M., Yan, J.X., Li, H.J., Wang, X., He, J.Z., Ding, G.W., 2013. Effects of different regeneration scenarios and fertilizer treatments on soil microbial ecology in reclaimed opencast mining areas on the Loess Plateau China. PloS One 8.

Lu, R., 2000. Soil Agrochemical Analysis Method. China Agricultural Science Technology Press, Beijing, China.

Lupatini, M., Jacques, R.J.S., Antoniolli, Z.I., Suleiman, A.K.A., Fulthorpe, R.R., Roesch, L.F.W., 2013. Land-use change and soil type are drivers of fungal and archaeal communities in the pampa biome. World J Microb Biot 29, 223-233.

Mariotte, P., Vandenberghe, C., Meugnier, C., Rossi, P., Bardgett, R.D., Buttler, A., 2013. Subordinate plant species impact on soil microbial communities and ecosystem functioning in grasslands: findings from a removal experiment. Perspect. Plant Ecol. 15, 77-85.

Salam, A.K., Katayama, A., Kimura, M., 1998. Activities of some soil enzymes in different land use systems after deforestation in hilly areas of West Lampung, South Sumatra, Indonesia. Soil Sci. Plant Nutr. 44, 93-103.

Schimann, H., Petit-Jean, C., Guitet, S., Reis, T., Domenach, A.M., Roggy, J.C., 2012. Microbial bioindicators of soil functioning after disturbance: the case of gold mining in tropical rainforests of French Guiana. Ecol. Indic. 20, 34-41.

Sinsabaugh, R.L., Hill, B.H., Shah, J.J.F., 2010. Ecoenzymatic stoichiometry of microbial organic nutrient acquisition in soil and sediment. Nature 122 (vol 462, p. 795,2009$)$.

Sinsabaugh, R.L., Lauber, C.L., Weintraub, M.N., Ahmed, B., Allison, S.D., Crenshaw, C., Contosta, A.R., Cusack, D., Frey, S., Gallo, M.E., Gartner, T.B., Hobbie, S.E., Holland, K., Keeler, B.L., Powers, J.S., Stursova, M., Takacs-Vesbach, C., Waldrop, M.P.,
Wallenstein, M.D., Zak, D.R., Zeglin, L.H., 2008. Stoichiometry of soil enzyme activity at global scale. Ecol. Lett. 11, 1252-1264.

Šourková, M., Frouz, J., Fettweis, U., Bens, O., Hüttl, R., Šantrǔčková, H., 2005. Soil development and properties of microbial biomass succession in reclaimed post mining sites near Sokolov (Czech Republic) and near Cottbus (Germany). Geoderma 129, 73-80.

Susyan, E.A., Wirth, S., Ananyeva, N.D., Stolnikova, E.V., 2011. Forest succession on abandoned arable soils in European Russia - impacts on microbial biomass, fungal-bacterial ratio, and basal $\mathrm{CO}_{2}$ respiration activity. Eur. J. Soil Biol. 47, 169-174.

Ter Braak, C.J.F., Šamilauer, P., 2002. CANOCO Reference Manual and CanoDraw for Wiindows User's Guide: Software for Canonical Community Ordination (Version 4.5). Microcomputer Power, Ithaca, NY USA, pp. 500.

Tischer, A., Blagodatskaya, E., Hamer, U., 2014. Extracellular enzyme activities in a tropical mountain rainforest region of southern Ecuador affected by low soil $\mathrm{P}$ status and land-use change. Appl. Soil Ecol. 74, 1-11.

Wallenius, K., Rita, H., Mikkonen, A., Lappi, K., Lindstrom, K., Hartikainen, H., Raateland, A., Niemi, R.M., 2011. Effects of land use on the level, variation and spatial structure of soil enzyme activities and bacterial communities. Soil Biol. Biochem. 43, 1464-1473.

Yoshitake, S., Fujiyoshi, M., Watanabe, K., Masuzawa, T., Nakatsubo, T., Koizumi, H., 2013. Successional changes in the soil microbial community along a vegetation development sequence in a subalpine volcanic desert on Mount Fuji, Japan. Plant Soil 364, 261-272.

Zhang, H., Li, G., Song, X., Yang, D., Li, Y., Oiao, J., Zhang, J., Zhao, S., 2013. Changes in soil microbial functional diversity under different vegetation restoration patterns for Hulunbeier sandy land. Acta Ecol. Sin. 33, $38-44$ 